\title{
Effect of proteasome inhibitor MG132 on the expression of oxidative metabolism related genes in tomato
}

\author{
Burcu KARPUZ1, Özgür ÇAKIR ${ }^{2 *}$ (D)
}

\begin{abstract}
Expression analysis of antioxidant related genes may provide key information to develop plants more tolerant to abiotic and biotic stress. For this purpose, in this study, proteosome was inhibited by using MG132 proteosome inhibitor in Lycopersicon esculentum (tomato) tissues with high antioxidant content. We aimed to explain the response of gene isoforms associated with oxidative stress metabolism as a result of proteasome inhibition induced by MG132 in tomato. Gene expression levels of SLGR1, SLPhGPX, SLCAT1, SLFe-SOD, SLGPX, SLCu/Zn-SOD, SLcAPX and SLGST genes which are known to be associated with antioxidant mechanisms, were determined by real-time PCR in tomato. There was no significant change in SLPhGPX, SLCAT1, SL-Fe-SOD and SLCAPX genes in root, stem and leaf tissues. In addition, expression of SLGR1 and SLGST genes in root tissue was increased. In leaf tissue, expression of SLGPX, SLCU/Zn-SOD and SLGST genes increased significantly. There was no significant change in the expression of the genes studied in the shoot tissue. These results obtained from tomato root, stem and leaf tissues by creating proteasome inhibition will help to understand the relationship between antioxidant system and proteasome system in plants.
\end{abstract}

Keywords: tomato; Lycopersicon esculentum; MG132; proteasome; antioxidants.

Practical Application: Tomato antioxidant capacity for cultivating in different stress conditions.

\section{Introduction}

Plants encounter many abiotic and biotic stress factors that adversely affect their growth and development throughout their life cycles (Gull et al., 2019). As a result of various abiotic stress conditions, plants produce reactive oxygen species (ROS) and are exposed to oxidative stress (Azooz \& Nabi, 2014; Prasad et al., 1994; Shi et al., 2015). Plants have various antioxidants that provide detoxification of ROS in order to survive and cope with oxidative stress. Enzymatic components of the antioxidant defense system are; Superoxide Dismutase (SOD), Iron Superoxide Dismutase (Fe-SOD), Copper Zinc Superoxide Dismutase (Cu/Zn-SOD), Catalase (CAT), Glutathione Peroxidase (GPX), Phospholipid Hydroperoxide Glutathione Peroxidase (PhGPX), Ascorbate Peroxidase (APX), Glutathione-S Transferase (GST) and Glutathione Reductase (GR).These enzymes work in different cell sections and when cells are exposed to oxidative stress, they respond to stress (Blokhina et al., 2003; Noctor \& Foyer, 1998). By regulating gene expression in the cell, antioxidant production is altered and the damage caused by oxidative stress is reduced. For instance, an increase in $\mathrm{Mn}$-SOD and Fe-SOD activity has been reported in the Suaeda salsa plant under salinity stress (Qiu-Fang et al., 2005). In addition, tolerance to oxidative stress in tobacco and Arabidopsis has been shown to increase as a result of overexpression of the $t A P X$ gene (Yabuta et al., 2002). Similarly, expression of CAT1, SOD1 and FER1 under abiotic stresses reveal important roles of ROS genes, especially to tolerate salinity and drought (Jithesh et al., 2006a, b). However, it has been reported that the cell response to oxidative stress is reported to differently in different plant species. In addition, the responses of antioxidant defense systems to stress conditions depend on plant and stress conditions and the duration of stress treatment. For instance, while the expression of two GPX isoforms increased under osmotic and methyl viologen stress in barley (Hordeum vulgare), it was also determined that the expression of the third GPX isoform decreased under these conditions (Churin et al., 1999).

The ubiquitin proteasome system (UPS) has been identified as an important system that plays a role in the processes of cell division, development, and response to abiotic and biotic stress in plants. It protects the cellular homeostasis by breaking or processing damaged, misfolded and short-lived proteins in the cell. Plants use various transcriptional, post-transcriptional and post-translational mechanisms to regulate stress perception, signal and responses. Ubiquitination, which functions in eukaryotic cells, is also a posttranslational modification and its main purpose is to mark proteins and degrade in $26 \mathrm{~S}$ proteasomes (Swatek \& Komander, 2016). Proteasome inhibitors have been the main means of determining the role of ubiquitin in different biological processes of the proteasome system. MG132 is a strong, reversible, synthetic peptide aldehyde group proteasome inhibitor (Hayashi et al., 1992; Ito et al., 1975). Studies have shown 
that cells affected by proteasome inhibition have higher ROS production. Accordingly, proteasomes are the direct regulatory mechanism of ROS production in plants (Kim et al., 2003). The relationship between proteasome inhibition and oxidative stress is well defined in yeast and mammalian cells. However, the information about the response mechanisms of proteasome inhibition in plants is limited.

Tomato (Lycopersicon esculentum Mill.) is a plant species belongs to Solanaceae family, which is widely used in the world and has economic importance. Tomato, known to have a good antioxidant content, is one of the well-studied plant species in genetic research (Barone et al., 2008; Jenkins, 1948). In our study, Lycopersicon esculentum wild species were grown in Alfred Heilbronn Botanical Garden of Istanbul University and the seeds were used in tissue culture. MG132 was used for proteasome inhibition in tissues of Lycopersicon esculentum. Expression levels of SLGR1, SLPhGPX, SLCAT1, SLFe-SOD, SLGPX, SLCU/Zn-SOD, SLCAPX and SLGST genes were determined by real-time PCR (qPCR) in MG132 treated tissues. It is suggested that the expression alterations of these genes in tomato root, stem and leaf tissues by creating proteasome inhibition will elucidate the role of proteasome on antioxidant mechanism.

\section{Materials and methods}

\subsection{Plant material and seed collecting}

L. esculentum (tomato) seeds were provided from Centre for Genetic Resources the Netherlands, Wageningen University and Research Center (CGN) by Dr. Bilgin Candar Çakır for previous works and we used them by her courtesy. Plant growing and seed production were carried out in Istanbul University, Faculty of Science, Department of Biology for the production of tomato seeds.

\subsection{Media preparation and growth conditions}

Murashige and Skoog (MS) media, which are widely preferred for in vitro studies, were used for the tissue culture of tomato (Murashige \& Skoog, 1962). The seeds were surface sterilized with $70 \%$ ethyl alcohol for $15-20 \mathrm{~s}$ and commercial bleach for 8-10 min. For washing, it was washed 3 times for $10 \mathrm{~min}$ in distilled water and dried on sterile paper. After surface sterilization of seeds, cultures were established in Petri dish containing Murashige and Skoog (MS) medium supplemented with 3\% (w/v) sucrose and $0.9 \%(\mathrm{w} / \mathrm{v})$ agar. The $\mathrm{pH}$ of the MS medium was adjusted to 5.8 and sterilized by autoclaving at $121^{\circ} \mathrm{C}, 1.2 \mathrm{~atm}$ pressure for $15 \mathrm{~min}$. Tomato plants were germinated for 17 days in plant growth chamber with conditions of $16 \mathrm{~h}$ light $/ 8 \mathrm{~h}$ dark at $25^{\circ} \mathrm{C}$ and used in experimental studies.

\subsection{Proteasome inhibitor treatment}

Proteasome inhibition was performed with $50 \mu \mathrm{M}$ MG132 proteasome inhibitor (EMD Millipore, 474787) in tomato root, stem and leaf tissues. Dimethyl sulfoxide (DMSO) was used as the solvent to prepare $50 \mu \mathrm{M}$ MG132 proteasome inhibitor solution. For inhibitor treatment, the roots, stems and leaves of 17 day old tomato plants growing in MS medium were separated and transferred to $1.5 \mathrm{~mL}$ eppendorf tubes. $1 \mathrm{~mL} 50 \mu \mathrm{M}$ MG132 proteasome inhibitor solution was added to the tubes and kept at room temperature for 24 hours. Tissues that were kept in DMSO for 24 hours were accepted as the control group. After inhibitor treatment, the collected samples were used freshly for molecular analysis.

\subsection{RNA extraction and cDNA synthesis}

For qPCR analysis, RNA isolations were performed in accordance with the protocol recommended by the manufacturer of the solution Trizol (Invitrogen, 15596026). The absorbance values of RNA samples at 260 and $280 \mathrm{~nm}$ wavelengths were measured using nanodrop spectrophotometer device (Thermo Scientific, Nanodrop 2000). A260/A280 ratio was used to determine the purity of RNA samples and RNAs with $\approx 2.0$ were considered pure. cDNA was synthesized from the isolated RNAs according to the High Capacity cDNA Reverse Transcription Kit (Applied Biosystem, 00709629) manufacturer protocol.

\subsection{Gene expression by qPCR}

qPCR analyzes were performed with BIORAD CFX96 instrument and $\Delta \Delta \mathrm{Ct}$ values were determined. Then, the expression coefficients of the genes were calculated using the $2^{-\Delta \Delta \mathrm{CT}}$ formula. Gene expression in terms of fold changes between the control and experimental groups (sample A and sample B) can be calculated using the $2^{-\Delta \Delta C T}$ formula $\left[\left(C_{T}\right.\right.$ target gene $-C_{T}$ internal control $)$ sample $A-\left(C_{T}\right.$ target gene $-C_{T}$ internal control $)$ sample B] (Schmittgen \& Livak, 2008). All qPCR reactions were designed in triplicate with internal control, negative control, NTC (no template control) and were carried out with a total volume of $20 \mu \mathrm{L}$. Each reaction tube contained $2 \mu \mathrm{L}$ cDNA (template), $1 \mu \mathrm{L}$ primer (forward and reverse), $10 \mu \mathrm{L}$ SYBR Green Master Mix and $6 \mu \mathrm{L}$ nuclease-free $\mathrm{dH}_{2} \mathrm{O}$. The $\mathrm{qPCR}$ conditions were set as follows, respectively: $90^{\circ} \mathrm{C}$ for $10 \mathrm{~min}$, then followed by 45 amplification cycles of $90^{\circ} \mathrm{C}$ for $15 \mathrm{sec}, 60^{\circ} \mathrm{C} / 62^{\circ} \mathrm{C} / 57.5^{\circ} \mathrm{C}$ for $1 \mathrm{~min}\left(60^{\circ} \mathrm{C}\right.$ for Actin, SLGR, SLPhGPX, SLCAT1, SLFe-SOD, SLGPX, SLCu/Zn-SOD, $62^{\circ} \mathrm{C}$ for Actin and SLGST, $57.5^{\circ} \mathrm{C}$ for Actin and SLcAPX), $72^{\circ} \mathrm{C}$ for $30 \mathrm{sec}$ and finally $60^{\circ} \mathrm{C}$ for $5 \mathrm{sec}$. Actin - the housekeeping gene, was used as the internal control for qPCR normalization. NCBI Primer-Blast was used for primer (SIGST, SlFe-SOD, SIGPX) design with tomato sequences available at Sol Genomics Network (Fernandez-Pozo et al., 2015). Sequences and accession numbers of all primers used for expression analysis of genes are listed in Table 1. Heat-map was generated using JColorGrid to demonstrate the change in expression profiles of antioxidant related SLGR1, SLPhGPX, SLCAT1, SLFe-SOD, SLGPX, SLCu/Zn-SOD, SLCAPX and SLGST genes (SourceForge, 2020; Joachimiak et al., 2006).

\subsection{Statistical analysis}

In our study, gene expression experiments were performed three biological and three technical in triplicate. One-way variance analysis - One-Way-ANOVA Tukey test was performed using Graphpad Prism ${ }^{\oplus} 8$ trial version to condition the statistical significance of gene expression analysis at $P \leq 0.05$ and standard error was determined. 
Table 1. Primer sequences of the antioxidants-related genes used in qPCR experiment.

\begin{tabular}{|c|c|c|c|}
\hline \multirow{2}{*}{ Primers } & \multirow{2}{*}{ Accession (SGN) } & Forward & \multirow{2}{*}{ References } \\
\hline & & Reverse & \\
\hline \multirow{2}{*}{ SlGR1 } & \multirow{2}{*}{ Solyc09g091840 } & 5’TTGGTGGAACGTGTGTTCTT3’ & \multirow{2}{*}{ Martinez et al. (2018) } \\
\hline & & 5’ТCTCAТТСАСТТСССАТССАЗ’ & \\
\hline \multirow{2}{*}{ SlPhGPX } & \multirow{2}{*}{ Solyc06g073460 } & 5’TGGCTTGAGCACTACAGGTG3’ & \multirow{2}{*}{ Martinez et al. (2018) } \\
\hline & & 5’TTTCGTAGGCAGGGAAGAAG3' & \\
\hline \multirow{2}{*}{ SICAT1 } & \multirow{2}{*}{ Solyc12g094620 } & 5’TGATCGCGAGAAGATACCTG3' & \multirow{2}{*}{ Martinez et al. (2018) } \\
\hline & & 5'CTTCCACGTTCATGGACAAC3' & \\
\hline \multirow{2}{*}{ SlCu/Zn-SOD } & \multirow{2}{*}{ Solyc11g066390 } & 5'GGCCAATCTTTGACCCTTTA3' & \multirow{2}{*}{ Martinez et al. (2018) } \\
\hline & & 5’AGTCCAGGAGCAAGTCCAGT3' & \\
\hline \multirow{2}{*}{ SlcAPX } & \multirow{2}{*}{ Solyc06g005160 } & 5’TCTGAATTGGGATTTGCTGA3’ & \multirow{2}{*}{ Martinez et al. (2018) } \\
\hline & & 5’CGTCTAACGTAGCTGCCAAA3' & \\
\hline \multirow{2}{*}{ SlGST } & \multirow{2}{*}{ Solyc01g086680 } & 5’AGCTCAAATGCACAATAAGCAGG3' & \multirow{2}{*}{ Designed in this study } \\
\hline & & 5’TCCTGGCAGGCATTTTGTCT3’ & \\
\hline \multirow{2}{*}{ SlFe-SOD } & \multirow{2}{*}{ Solyc06g048410 } & 5’GGAGAACCCAAAAGAAACAATTTGG3' & \multirow{2}{*}{ Designed in this study } \\
\hline & & 5’TGAGGCTCCAAAGCATCCAT3' & \\
\hline \multirow{2}{*}{ SIGPX } & \multirow{2}{*}{ Solyc08g080940 } & 5’CTCGCGTTCTTCTCATCCCA3' & \multirow{2}{*}{ Designed in this study } \\
\hline & & 5'GGTAAAACTGTTCGGATCGGC3' & \\
\hline \multirow{2}{*}{ SlActin } & \multirow{2}{*}{ Solyc03g078400 } & 5'CCTCAGCACATTCCAGCAGA3' & \multirow{2}{*}{ Designed in this study } \\
\hline & & 5'CAGACAGGACACTCGCACTT3' & \\
\hline
\end{tabular}

\section{Results}

\subsection{Proteasome inhibitor treatment}

Collected seeds were incubated in the plant growth chamber after surface sterilization and seeds began to germinate after approximately 7 days. After the fourth leaves of the plants grown on MS medium were formed at the end of 17 days, leaf, root and stem tissues were harvested and used in experiments (Figure 1).

\subsection{RNA isolation and qPCR analysis}

$50 \mu \mathrm{M}$ MG132 proteasome inhibitor treated L. esculentum root, stem and leaf tissues expression analysis results of $S L G R 1$, SLPhGPX, SLCAT1, SLFe-SOD, SLGPX, SLCU/Zn-SOD, SLcAPX and SLGST genes are given in Figures 2 and 3. The bars in the graphs show the standard error $( \pm \mathrm{SH})$ in 3 replicate experiments. Significant change of SLGR1, SLGPX, SLCu/Zn-SOD, SLGST genes after qPCR analysis is summarized in the graphs given in Figure 2.

Expression of the SLGR1 gene increased 1.30 times as a result of $50 \mu \mathrm{M}$ MG132 treatment in the root, while there was no significant change in leaf and stem tissue. In addition, while the expression of the SLGPX gene increased 2.71 times in leaf tissue, there was no significant change in root and stem tissue. Although the expression of $S L C U / Z n-S O D$ gene increased 2.43 times in leaf tissue, there was a decrease in root and stem tissues compared to leaf tissue.

However, there was no significant change in root and stem tissue compared to the actin gene. While expression of SLGST gene increased 5.45 times in leaf tissue and 2.63 times in root tissue; no significant change in stem tissue was observed.

The effect of proteasome inhibition on the expression of SLPhGPX, SLCAT1, SLFe-SOD and SLCAPX genes in L. esculentum root, stem and leaf tissue is shown in Figure 3. The administration

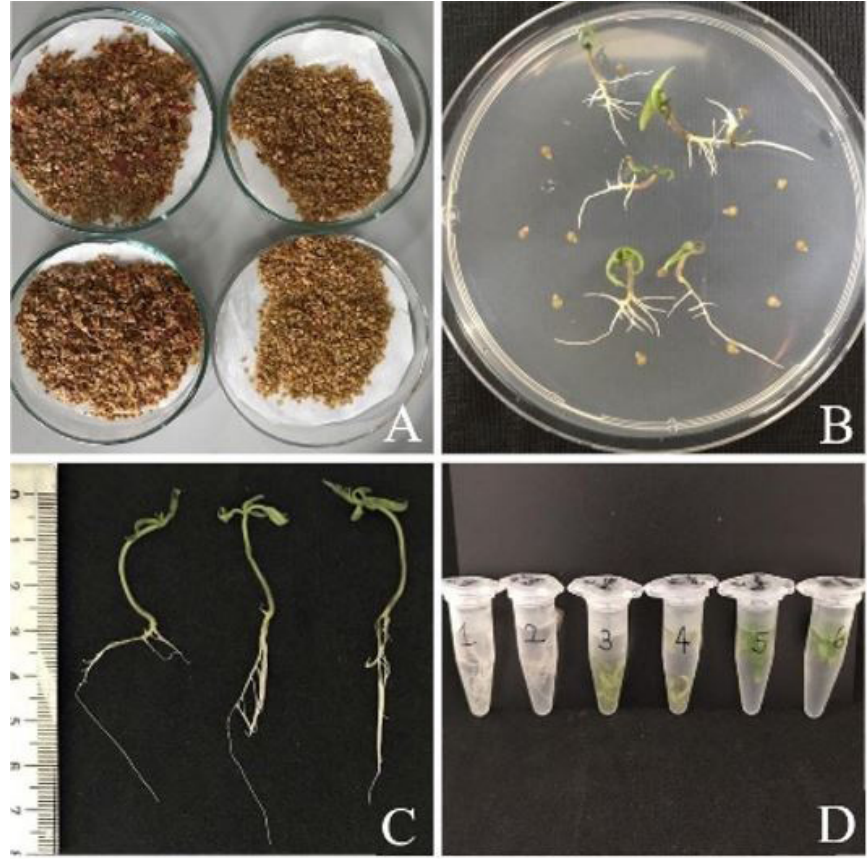

Figure 1. (A) represents seeds of L. esculentum dried for 24-48 hours; (B) represents day old plants on MS medium; (C) represents 17 day old plants; (D) represents control DMSO and MG132 proteasome inhibitor treatment.

of $50 \mu \mathrm{M} \mathrm{MG132}$ proteasome inhibitor does not change the expression of these genes relative to the actin gene. The diagram showing the expression of each gene for leaf, root and stem tissue is given in Figure 4.

\section{Discussion}

Lycopersicon esculentum (tomato) is a favoured plant in genetic research because of its agricultural importance and 

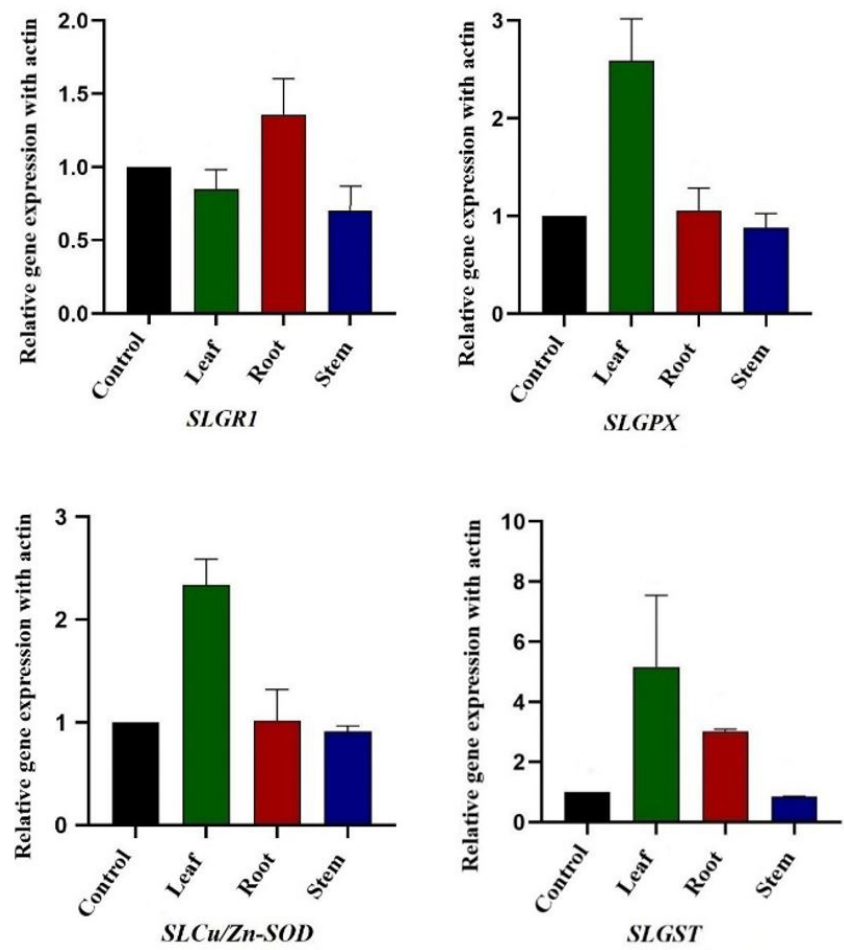

Figure 2. Graphs of expression levels of SLGR1, SLGPX, SLCu/Zn-SOD, SLGST genes in L. esculentum leaf, root and stem tissue as a result of qPCR analysis.
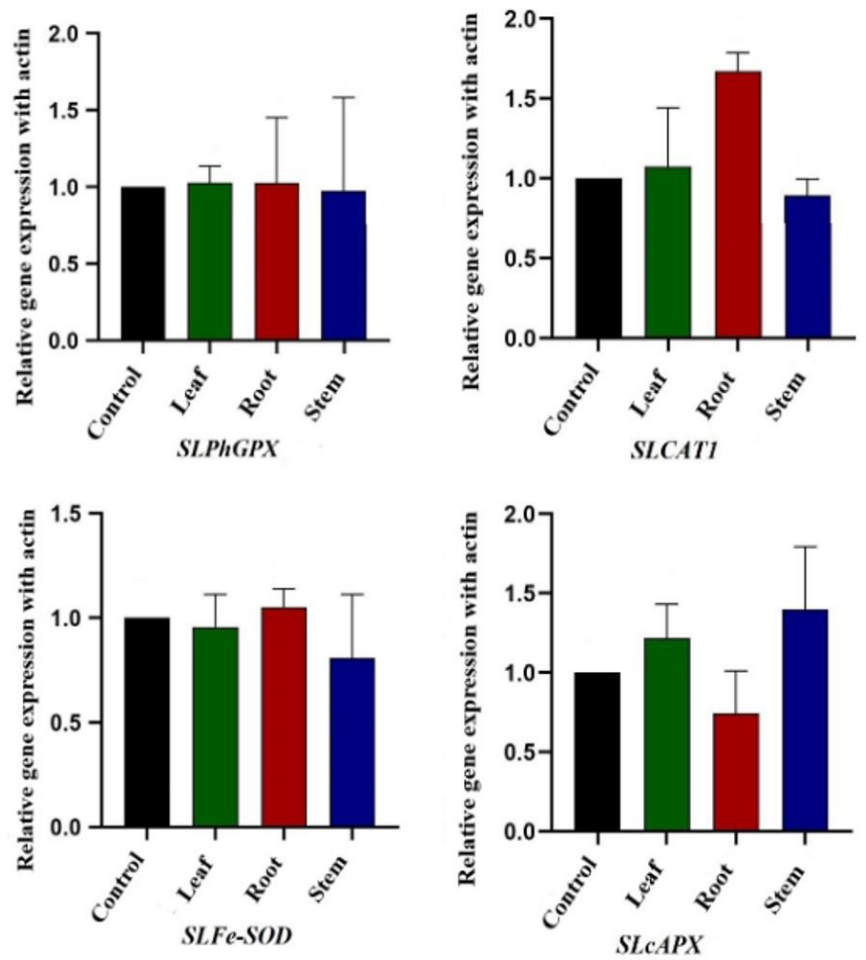

Figure 3. Graphical representation of the expression levels of $S L P h G P X$, SLCAT1, SLFe-SOD and SLCAPX genes in L. esculentum leaf, root and stem tissue as a result of qPCR analysis.

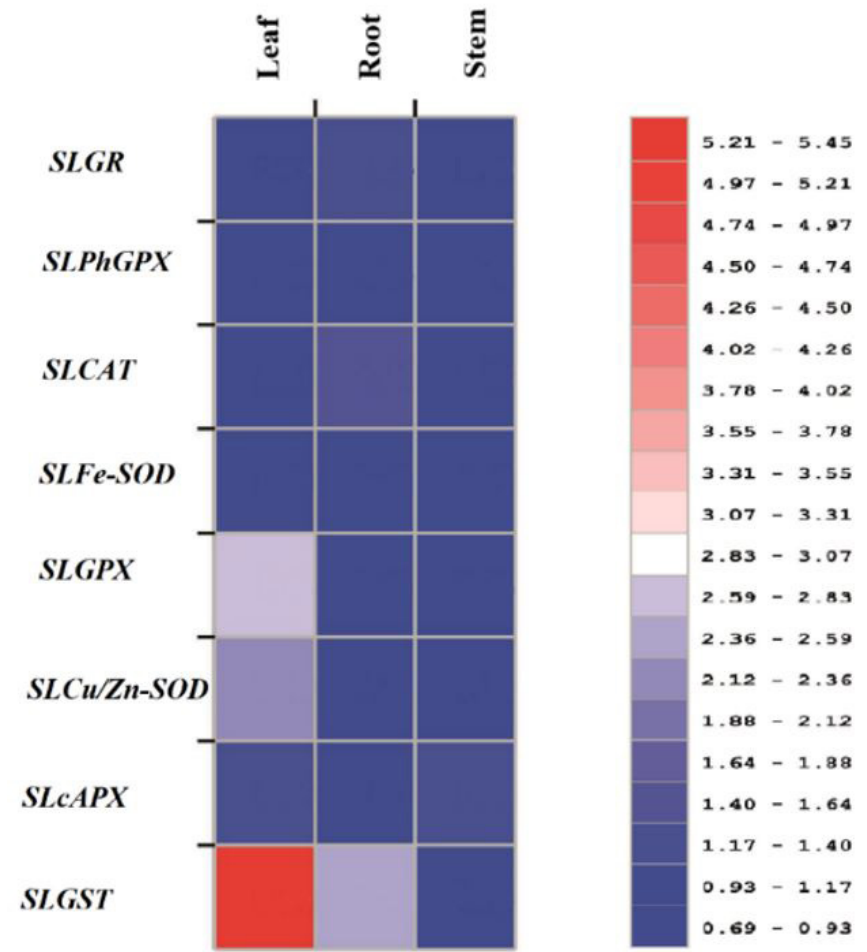

Figure 4. Diagram showing the expression of each gene for leaf, root and stem tissue.

short life cycle. It is also a good source of antioxidants. Various compounds of fruits have been reported to have antioxidant and anticancer properties and have been used in health studies (Abewoy Fentik, 2017; Giovannucci, 1999; Lenucci et al., 2006; Raiola et al., 2014).

In plants, salinity, drought, high light and toxicity from metals increase the production of reactive oxygen species (ROS) in the cell. ROS also causes oxidative stress and degradation of biological macromolecules (lipids, carbohydrates, proteins and nucleic acids). It is known that proteolysis mechanism is known to be important in growth, development, protein synthesis and organelle biogenesis processes in organisms. The degradation of proteins involved in these stages provides cellular homeostasis.

Ubiquitin-proteasome system (UPS) is the main mechanism that provides the degradation of proteins transferred from the cytoplasm and nucleus in eukaryotes (Bolwell, 2001). Proteasome inhibitors are used to inhibit proteasome activity in laboratory experiments (Kisselev \& Goldberg, 2001). When the proteasome system is inhibited, damaged, misfolded and short-lived proteins accumulate inside the cell. Moreover, DNA breaks and high levels of ROS are produced (Kim et al., 2003; Stadtman \& Berlett, 1998). Previous studies have shown that ROS production in cells is increased as a result of proteasome inhibition. Plant genomes are known to encode more UPS components than other eukaryotes. This indicates that UPS performs important functions in various cellular processes in plants. Antioxidant enzyme activities in plants are one of the important mechanisms of resistance against oxidative stress that turn ROS into harmless compounds, which reach high levels due to proteasome inhibition stress. Moreover, it is known that proteasomes act as a direct 
regulatory mechanism of ROS production. MG132 is widely used to block the proteolytic activity of the $26 \mathrm{~S}$ proteasome complex and causes the formation of reactive oxygen species (Han et al., 2010; Wu et al., 2002). In Arabidopsis, 26S proteasome function was inhibited by the MG132 proteasome inhibitor, and a significant increase in HsfA2 (Heat shock transcription factor A2) expression in response to oxidative stress was reported (Nishizawa-Yokoi et al., 2010). A current study characterizing the global gene profile of MG132 showed that inhibition of the proteasome led to gene expression alterations at the transcription level associated with protein metabolism, oxidative stress, GSH activity, and cell cycle control (Yu et al., 2010). In a study with white spruce (Picea glauca), the role of the ROS and ubiquitinproteasome pathway in regulation was investigated, and it was reported that inhibition of proteasome with MG132 treatment increased CAT activity (He \& Kermode, 2010). Consequently, the ubiquitin-proteasome pathway appears to modulate ROS scavenging enzymes. In this study, a reversible and synthetic peptide aldehyde group proteasome inhibitor MG132 was used to induce the oxidative stress and the expression alterations of $S L G R 1$, SLPhGPX, SLCAT1, SLFe-SOD, SLGPX, SLCU/Zn-SOD, SLcAPX and SLGST genes, which are known related with antioxidant mechanisms, were demonstrated.

Catalase (CAT) is an enzyme that converts hydrogen peroxide $\left(\mathrm{H}_{2} \mathrm{O}_{2}\right)$ to water $\left(\mathrm{H}_{2} \mathrm{O}\right)$ and oxygen $\left(\mathrm{O}_{2}\right)$ weighing about 200-340 kDa. Multiple catalase forms have been identified in various plants in previous studies. In maize catalases are divided into three isoenzyme groups known as CAT1, CAT2 and CAT3, and these isoenzymes are encoded by the Cat1, Cat 2 and Cat 3 structural genes, respectively. In $A$. thaliana, catalase has been found to be encoded by a small family of genes, which are three gene members called cat1-3. It has been shown in previous studies that catalase genes have different effects in Arabidopsis (Li et al., 2015; Mhamdi et al., 2010). The expression of each of the Cat genes is known to be highly regulated with subject to time and various environmental signals (Scandalios et al., 1997; Zámocký et al., 2012). The increase in catalase activity under multiple abiotic stress conditions was reported in several studies (Karam et al., 2017; Mahmud et al., 2017; Zhou et al., 2017). Our results showed that there was no significant change in the expression of SlCAT1 gene encoding L. esculentum CAT1 isoform in root, stem and leaf tissue. The role of the catalase enzyme in the cell is to detoxify $\mathrm{H}_{2} \mathrm{O}_{2}$ to protect the cells from oxidative damage. However, the efficiency of CAT protecting cells from $\mathrm{H}_{2} \mathrm{O}_{2}$ is very limited. The reason for this is that CAT's interest in $\mathrm{H}_{2} \mathrm{O}_{2}$ is lower compared to other enzymes and its inactivated in the presence of light (Prasad, 1997). According to this information, it is doubtful to consider the activity of the catalase enzyme or the change in catalase genes as a stress marker in plants. In this study, the absence of a significant change in SlCAT1 gene in response to oxidative stress caused by proteasome inhibition suggested that catalase may be due to less interest in $\mathrm{H}_{2} \mathrm{O}_{2}$.

According to a study in transgenic poplar plants, it has been reported that the activity of Fe-SOD (one of the isoforms of SOD) increases under low $\mathrm{CO}_{2}$ conditions and this has a protective effect on photosystem II (PSII) (Arisi et al., 1998). In a study in Arabidopsis, FSD2 gene expression increased in response to high light stress from three Fe-SOD genes (FSD1, FSD2 and FSD3) under oxidative stress conditions. However, it has been reported that there is no change in the expression of FSD2 gene against ozone stress (Kliebenstein et al., 1998). Avc1 Duman et al. (2016), reported that in Amsonia orientalis, $\mathrm{H}_{2} \mathrm{O}_{2}$ and MDA levels increase in parallel with increasing salt stress concentrations and salt stress inhibits Fe-SOD and $\mathrm{Cu} / \mathrm{Zn}-\mathrm{SOD}$ activities as a result of electrophotometric analyzes. In this study, it was determined that there was no significant change in the expression of the $S L F e-S O D$ gene in root, stem and leaf tissue. These results may indicate that Fe-SOD activity is not effective in response to oxidative stress caused by proteasome inhibition in $L$. esculentum, or increased $\mathrm{H}_{2} \mathrm{O}_{2}$ level in accordance with other studies may cause $\mathrm{Fe}-\mathrm{SOD}$ inactivation.

The $\mathrm{Cu} / \mathrm{Zn}$-SOD enzyme is found only in eukaryotes and its various forms have been described in plants. The superoxide radical formed due to oxidative stress is converted into $\mathrm{H}_{2} \mathrm{O}_{2}$ and molecular oxygen with the enzyme $\mathrm{Cu} / \mathrm{Zn}-\mathrm{SOD}$ and provides the conversion of $\mathrm{H}_{2} \mathrm{O}_{2}$ to oxygen and water with APX and CAT enzymes. In plants, an increase in $\mathrm{Cu} / \mathrm{Zn}$-SOD gene expression has been reported under abiotic and biotic stress conditions (Van Camp et al., 1994; Wu, et al., 2016; Zhang et al., 2017). In this study, SLCu/Zn-SOD gene encoding Cu/Zn-SOD3 form was studied in L. esculentum. SLCu/Zn-SOD gene expression was increased 2.43 times in leaf tissue with proteasome inhibition in accordance with other studies and providing an antioxidant defense response for the transformation of superoxide radicals in cells.

APX is one of the most important antioxidant enzymes that provide detoxification of $\mathrm{H}_{2} \mathrm{O}_{2}$ in plants under stress conditions (Asada, 1992; Scandalios et al., 1997; Wang et al., 1999). In a study of transgenic tomato plants (Lycopersicon esculentum L.), overexpression of the cytosolic APX gene has been shown to improve oxidative damage caused by cold and salt stress (Wang et al., 2005). In addition, some studies have shown that the activity of APX decreases under stress conditions. It has been reported that tAPX (tilacoid-bonded) and sAPX (soluble) may inactivate under severe stress conditions such as heavy metal toxicity or drought in plants (Kitajima, 2008; Liu et al., 2008). Similarly, it was reported that APX activity decreased in L. esculentum and $L$. peruvianum plants applied drought stress compared to the control group (Ünyayar et al., 2005). In our study, it was determined that there was no significant expression change of the cytosolic SLCAPX gene with APX isoform in L. esculentum root, stem and leaf tissues. Studies show that enzyme activities and gene expression vary depending on the stress application time, intensity and species of the plant. According to the results obtained from this study, APX is not effective in cleaning ROS caused by proteasome inhibition in L. esculentum.

GPXle-1 is a GPX isoform with glutathione peroxidase activity, located in mitochondria and cytoplasm. GPXle-1 has been associated with oxidative stress response, similar to other GPX forms. It is known that the level of GPX mRNA in various organisms is affected by stress conditions (Bela et al., 2018; Islam et al., 2015; Sugimoto \& Sakamoto, 1997). Additionally, it is known that GPX enzymes act on $\mathrm{H}_{2} \mathrm{O}_{2}$ and respond against oxidative damage and provides the destruction of lipid hydroperoxides with GSH and plays a role in preventing cellular 
damage (Muller et al., 2007; Sen \& Chakraborty, 2011). Our results showed that the expression of the SLGPX gene in L. esculentum encoding the GPXle-1 isoform increased 2.71 times in leaf tissue suggesting this increase leads to the degradation of $\mathrm{H}_{2} \mathrm{O}_{2}$ and lipid hydroperoxides caused by proteasome inhibition.

The role of PhGPX (GPX isoform) in plants is not exactly known, but it has been reported to provide ROS detoxification and removal of lipid hydroperoxides under abiotic and biotic stresses. According to gene expression analysis, PhGPX mRNA levels have been reported to increase in various plants exposed to biotic and abiotic stresses such as pathogen infections, heavy metal, oxidative stress (Avsian-Kretchmer et al., 1999; Criqui et al., 1992; Sugimoto \& Sakamoto, 1997). In this study, it was observed that there was no significant change in the expression of the $S L P h G P X$ gene in root, stem and leaf tissue. Our results showed that PhGPX enzyme is not effective in ROS detoxification due to proteasome inhibition in L. esculentum. The absence of changes in antioxidant enzyme activities may suggest that the responses of plants to stress conditions depend on the plant species, stress condition, and time of stress treatment.

GR enzyme are known to provide $\mathrm{H}_{2} \mathrm{O}_{2}$ detoxification. It has been observed that overexpression of GR provides tolerance to oxidative stress in N. tabacum and Populus plants (Foyer et al., 1995; Van Camp et al., 1996). As a result of oxidative stress caused by drought stress, it was reported that GR activity increased in Lycopersicon esculentum, L. notabilis, Cucumis sativus compared to the control group (Ünyayar \& Çekiç, 2005; Liu et al., 2009). In this study, in accordance with other studies, it was determined that SLGR1 gene expression encoding the GR form localized in mitochondria increased 1.30 times compared to control. In L. esculentum root tissue, suggesting that there is an antioxidant response to the removal of increased ROS in cells caused by proteasome inhibition.

GSTs are important antioxidant enzymes that regulate oxidative stress metabolism. GST enzymes act mainly with GSH and remove lipid peroxides and ROS that accumulate in cells. Several studies show that GSTs can protect plants from different environmental stresses, including heavy metal stress and UV radiation (Ding et al., 2017; Liu \& Li, 2002). In this study, the expression of the SLGST gene belonging to the theta class in response to proteasome inhibition in L. esculentum increased 2.63 times in the root and 5.45 times in the leaf. In accordance with these results, GST activity increase in L. esculentum root and leaf tissues provides detoxification of ROS caused by proteasome inhibition.

Expression analysis results of antioxidant-related genes allow to elucidate abiotic stress and signal transduction pathways and subsequently to clarify abiotic stress tolerance mechanism. Our study revealed the response of tomato genes related to oxidative stress metabolism with proteasome inhibition. As a result of $50 \mu \mathrm{M}$ MG132 treatment in tomato, SLGR1 and SLGPX expressions increased in root and leaf tissues, respectively. $S L C u / Z n-S O D$ expression also increased in root and leaf tissues. The increase in the expression of these genes in tomato tissues elucidates the role of antioxidant mechanism on removing possible ROS and protecting against cell damage. However, expression of SLPhGPX, SLCAT1, SLFe-SOD and SLCAPX genes did not change significantly in all three tissues as a result of proteasome inhibition indicating that these genes may not be effective in ROS clearance caused by proteasome inhibition. Consequently our results suggest that the association between proteasome system and the antioxidant mechanism contributes to develop abiotic stress tolerant plant species.

\section{Acknowledgements}

This work was supported by the Research Fund of The Istanbul University, Project No: FYL-2019-33578.

\section{References}

Abewoy Fentik, D. (2017). Review on genetics and breeding of tomato (Lycopersicon esculentum Mill). Advances in Crop Science and Technology, 5(5), 306. http://dx.doi.org/10.4172/2329-8863.1000306.

Arisi, A. C. M., Cornic, G., Jouanin, L., \& Foyer, C. H. (1998). Overexpression of iron superoxide dismutase in transformed poplar modifies the regulation of photosynthesis at low $\mathrm{CO}_{2}$ partial pressures or following exposure to the prooxidant herbicide methyl viologen. Plant Physiology, 117(2), 565-574. http://dx.doi.org/10.1104/ pp.117.2.565. PMid:9625709.

Asada, K. (1992). Ascorbate peroxidase: a hydrogen peroxide-scavenging enzyme in plants. Physiologia Plantarum, 85(2), 235-241. http:// dx.doi.org/10.1111/j.1399-3054.1992.tb04728.x.

Avcı Duman, Y., Acemi, A., Toygar, H., Yüzügüllü, Y., \& Özen, F. (2016). Investigation of antioxidant enzymes of Amsonia orientalis in the presence of salt stress and BAP. Celal Bayar University Journal of Science, 12(3), 543-551.

Avsian-Kretchmer, O., Eshdat, Y., Gueta-Dahan, Y., \& Ben-Hayyim, G. (1999). Regulation of stress-induced phospholipid hydroperoxide glutathione peroxidase expression in citrus. Planta, 209(4), 469-477. http://dx.doi.org/10.1007/s004250050750. PMid:10550628.

Azooz, M. M., \& Nabi, G. (2014). Generation of ROS and non-enzymatic antioxidants during abiotic stress in plants. Botany Research International, 2(1), 11-20.

Barone, A., Chiusano, M. L., Ercolano, M. R., Giuliano, G., Grandillo, S., \& Frusciante, L. (2008). Structural and functional genomics of tomato. International Journal of Plant Genomics, 2008, 820274. http:// dx.doi.org/10.1155/2008/820274. PMid:18317508.

Bela, K., Riyazuddin, R., Horváth, E., Hurton, Á., Gallé, Á., Takács, Z., Zsigmond, L., Szabados, L., Tari, I., \& Csiszár, J. (2018). Comprehensive analysis of antioxidant mechanisms in Arabidopsis glutathione peroxidase-like mutants under salt- and osmotic stress reveals organ-specific significance of the AtGPXL's activities. Environmental and Experimental Botany, 150, 127-140. http://dx.doi.org/10.1016/j.envexpbot.2018.02.016.

Blokhina, O., Virolainen, E., \& Fagerstedt, K. V. (2003). Antioxidants, oxidative damage and oxygen deprivation stress: a review. Annals of Botany, 91(2), 179-194. http://dx.doi.org/10.1093/aob/mcf118.

Bolwell, G. P. (2001). Biochemistry \& molecular biology of plants. Phytochemistry, 58(1), 185. http://dx.doi.org/10.1016/S00319422(01)00095-4.

Churin, Y., Schilling, S., \& Börner, T. (1999). A gene family encoding glutathione peroxidase homologues in Hordeum vulgare (barley). FEBS Letters, 459(1), 33-38. http://dx.doi.org/10.1016/S0014-5793(99)01208-9.

Criqui, M. C., Jamet, E., Parmentier, Y., Marbach, J., Durr, A., \& Fleck, J. (1992). Isolation and characterization of a plant cDNA showing homology to animal glutathione peroxidases. Plant Molecular Biology, 18(3), 623-627. http://dx.doi.org/10.1007/BF00040684. 
Ding, N., Wang, A., Zhang, X., Wu, Y., Wang, R., Cui, H., Huang, R., \& Luo, Y. (2017). Identification and analysis of glutathione S-transferase gene family in sweet potato reveal divergent GST-mediated networks in aboveground and underground tissues in response to abiotic stresses. BMC Plant Biology, 17(1), 225. http://dx.doi.org/10.1186/ s12870-017-1179-z.

Fernandez-Pozo, N., Menda, N., Edwards, J. D., Saha, S., Tecle, I. Y., Strickler, S. R., Bombarely, A., Fisher-York, T., Pujar, A., Foerster, H., Yan, A., \& Mueller, L. A. (2015). The Sol Genomics Network (SGN)from genotype to phenotype to breeding. Nucleic Acids Research, 43(Database issue), D1036-D1041. Available from http://solgenomics. net/. http://dx.doi.org/10.1093/nar/gku1195. PMid:25428362.

Foyer, C. H., Souriau, N., Perret, S., Lelandais, M., Kunert, K. J., Pruvost, C., \& Jouanin, L. (1995). Overexpression of glutathione reductase but not glutathione synthetase leads to increases in antioxidant capacity and resistance to photoinhibition in poplar trees. Plant Physiology, 109(3), 1047-1057. http://dx.doi.org/10.1104/pp.109.3.1047.

Giovannucci, E. (1999). Tomatoes, tomato-based products, lycopene, and cancer: review of the epidemiologic literature. Journal of the National Cancer Institute, 91(4), 317-331. http://dx.doi.org/10.1093/jnci/91.4.317.

Gull, A., Ahmad Lone, A., \& Ul Islam Wani, N. (2019). Biotic and abiotic stresses in plants. In A. Oliveira (Ed.), Abiotic and biotic stress in plants. London: IntechOpen. http://dx.doi.org/10.5772/ intechopen.85832.

Han, Y. H., Moon, H. J., You, B. R., Kim, S. Z., Kim, S. H., \& Park, W. H. (2010). The effects of N-acetyl cysteine on the MG132 proteasome inhibitor-treated lung cancer cells in relation to cell growth, reactive oxygen species and glutathione. International Journal of Molecular Medicine, 25(4), 657-662. PMid:20198316.

Hayashi, M., Saito, Y., \& Kawashima, S. (1992). Calpain activation is essential for membrane fusion of erythrocytes in the presence of exogenous $\mathrm{Ca}^{2+}$. Biochemical and Biophysical Research Communications, 182(2), 939-946. http://dx.doi.org/10.1016/0006-291X(92)91822-8. PMid:1734892.

He, X., \& Kermode, A. R. (2010). Programmed cell death of the megagametophyte during post-germinative growth of white spruce (Picea glauca) seeds is regulated by reactive oxygen species and the ubiquitin-mediated proteolytic system. Plant \& Cell Physiology, 51(10), 1707-1720. http://dx.doi.org/10.1093/pcp/pcq130.

Islam, T., Manna, M., Kaul, T., Pandey, S., Reddy, C. S., \& Reddy, M. K. (2015). Genome-wide dissection of arabidopsis and rice for the identification and expression analysis of glutathione peroxidases reveals their stress-specific and overlapping response patterns. Plant Molecular Biology Reporter, 33(5), 1413-1427. http://dx.doi. org/10.1007/s11105-014-0846-6.

Ito, A., Takahashi, R., Miura, C., \& Baba, Y. (1975). Synthetic Study of Peptide Aldehydes. Chemical \& Pharmaceutical Bulletin, 23(12), 3106-3113. http://dx.doi.org/10.1248/cpb.23.3106.

Jenkins, J. A. (1948). The origin of the cultivated tomato. Economic Botany, 2(4), 379-392. http://dx.doi.org/10.1007/BF02859492.

Jithesh, M. N., Prashanth, S. R., Sivaprakash, K. R., \& Parida, A. (2006a). Monitoring expression profiles of antioxidant genes to salinity, iron, oxidative, light and hyperosmotic stresses in the highly salt tolerant grey mangrove, Avicennia marina (Forsk.) Vierh. by mRNA analysis. Plant Cell Reports, 25(8), 865-876. http://dx.doi. org/10.1007/s00299-006-0127-4.

Jithesh, M. N., Prashanth, S. R., Sivaprakash, K. R., \& Parida, A. K. (2006b). Antioxidative response mechanisms in halophytes: Their role in stress defence. Journal of Genetics, 85(3), 237-254. http:// dx.doi.org/10.1007/BF02935340.
Joachimiak, M. P., Weisman, J. L., \& May, B. C. H. (2006). JColorGrid: software for the visualization of biological measurements. $B M C$ Bioinformatics, 7(1), 225. http://dx.doi.org/10.1186/1471-2105-7-225.

Karam, E. A., Maresca, V., Sorbo, S., Keramat, B., \& Basile, A. (2017). Effects of triacontanol on ascorbate-glutathione cycle in Brassica napus L. exposed to cadmium-induced oxidative stress. Ecotoxicology and Environmental Safety, 144, 268-274. http://dx.doi.org/10.1016/j. ecoenv.2017.06.035. PMid:28633105.

Kim, M., Ahn, J. W., Jin, U. H., Choi, D., Paek, K. H., \& Pai, H. S. (2003). Activation of the programmed cell death pathway by inhibition of proteasome function in plants. The Journal of Biological Chemistry, 278(21), 19406-19415. http://dx.doi.org/10.1074/jbc.M210539200. PMid:12637532.

Kisselev, A. F., \& Goldberg, A. L. (2001). Proteasome inhibitors: from research tools to drug candidates. Chemistry \& Biology, 8(8), 739-758. http://dx.doi.org/10.1016/S1074-5521(01)00056-4. PMid:11514224.

Kitajima, S. (2008). Hydrogen peroxide-mediated inactivation of two chloroplastic peroxidases, ascorbate peroxidase and 2-Cys peroxiredoxin. Photochemistry and Photobiology, 84(6), 1404-1409. http://dx.doi.org/10.1111/j.1751-1097.2008.00452.x.

Kliebenstein, D. J., Monde, R. A., \& Last, R. L. (1998). Superoxide dismutase in arabidopsis: an eclectic enzyme family with disparate regulation and protein localization. Plant Physiology, 118(2), 637650. http://dx.doi.org/10.1104/pp.118.2.637.

Lenucci, M. S., Cadinu, D., Taurino, M., Piro, G., \& Dalessandro, G. (2006). Antioxidant composition in cherry and high-pigment tomato cultivars. Journal of Agricultural and Food Chemistry, 54(7), 26062613. http://dx.doi.org/10.1021/jf052920c.

Li, J., Liu, J., Wang, G., Cha, J. Y., Li, G., Chen, S., Li, Z., Guo, J., Zhang, C., Yang, Y., Kim, W. Y., Yun, D. J., Schumaker, K. S., Chen, Z., \& Guo, Y. (2015). A chaperone function of No Catalase Activity1 is required to maintain catalase activity and for multiple stress responses in Arabidopsis. The Plant Cell, 27(3), 908-925. http:// dx.doi.org/10.1105/tpc.114.135095. PMid:25700484.

Liu, K. L., Shen, L., Wang, J. Q., \& Sheng, J. P. (2008). Rapid inactivation of chloroplastic ascorbate peroxidase is responsible for oxidative modification to Rubisco in tomato (Lycopersicon esculentum) under cadmium stress. Journal of Integrative Plant Biology, 50(4), 415-426. http://dx.doi.org/10.1111/j.1744-7909.2007.00621.x.

Liu, X. F., \& Li, J. Y. (2002). Characterization of an ultra-violet inducible gene that encodes glutathione S-transferase in Arabidopsis thaliana. Acta Genetica Sinica, 29(5), 458-460. PMid:12043576.

Liu, Z. J., Zhang, X. L., Bai, J. G., Suo, B. X., Xu, P. L., \& Wang, L. (2009). Exogenous paraquat changes antioxidant enzyme activities and lipid peroxidation in drought-stressed cucumber leaves. Scientia Horticulturae, 121(2), 138-143. http://dx.doi.org/10.1016/j. scienta.2009.01.032.

Mahmud, J., Hasanuzzaman, M., Nahar, K., Rahman, A., Hossain, M. S., \& Fujita, M. (2017). Maleic acid assisted improvement of metal chelation and antioxidant metabolism confers chromium tolerance in Brassica juncea L. Ecotoxicology and Environmental Safety, 144, 216-226. http://dx.doi.org/10.1016/j.ecoenv.2017.06.010.

Martinez, V., Nieves-Cordones, M., Lopez-Delacalle, M., Rodenas, R., Mestre, T. C., Garcia-Sanchez, F., Rubio, F., Nortes, P. A., Mittler, R., \& Rivero, R. M. (2018). Tolerance to stress combination in tomato plants: new insights in the protective role of melatonin. Molecules, 23(3), 535. http://dx.doi.org/10.3390/molecules23030535. PMid:29495548.

Mhamdi, A., Queval, G., Chaouch, S., Vanderauwera, S., Van Breusegem, F., \& Noctor, G. (2010). Catalase function in plants: A focus on Arabidopsis 
mutants as stress-mimic models. Journal of Experimental Botany, 61(15), 4197-4220. http://dx.doi.org/10.1093/jxb/erq282. PMid:20876333.

Muller, F. L., Lustgarten, M. S., Jang, Y., Richardson, A., \& Van Remmen, H. (2007). Trends in oxidative aging theories. Free Radical Biology \& Medicine, 43(4), 477-503. http://dx.doi.org/10.1016/j. freeradbiomed.2007.03.034. PMid:17640558.

Murashige, T., \& Skoog, F. (1962). A revised medium for rapid growth and bio assays with tobacco tissue cultures. Physiologia Plantarum, 15(3), 473-497. http://dx.doi.org/10.1111/j.1399-3054.1962.tb08052.x.

Nishizawa-Yokoi, A., Tainaka, H., Yoshida, E., Tamoi, M., Yabuta, Y., \& Shigeoka, S. (2010). The 26S proteasome function and Hsp90 activity involved in the regulation of $\mathrm{HsfA} 2$ expression in response to oxidative stress. Plant \& Cell Physiology, 51(3), 486-496. http:// dx.doi.org/10.1093/pcp/pcq015.

Noctor, G., \& Foyer, C. H. (1998). Ascorbate and glutathione: keeping active oxygen under control. Annual Review of Plant Physiology and Plant Molecular Biology, 49(1), 249-279. http://dx.doi.org/10.1146/ annurev.arplant.49.1.249.

Prasad, T. K. (1997). Role of catalase in inducing chilling tolerance in pre-emergent maize seedlings. Plant Physiology, 114(4), 1369-1376. http://dx.doi.org/10.1104/pp.114.4.1369.

Prasad, T. K., Anderson, M. D., Martin, B. A., \& Stewart, C. R. (1994). Evidence for chilling-induced oxidative stress in maize seedlings and a regulatory role for hydrogen peroxide. The Plant Cell, 6(1), 65-74. http://dx.doi.org/10.2307/3869675. PMid:12244221.

Qiu-Fang, Z., Yuan-Yuan, L., Cai-Hong, P., Cong-Ming, L., \& BaoShan, W. (2005). NaCl enhances thylakoid-bound SOD activity in the leaves of C3 halophyte Suaeda salsa L. Plant Science, 168(2), 423-430. http://dx.doi.org/10.1016/j.plantsci.2004.09.002.

Raiola, A., Rigano, M. M., Calafiore, R., Frusciante, L., \& Barone, A. (2014). Enhancing the health-promoting effects of tomato fruit for biofortified food. Mediators of Inflammation, 2014, 1-16. http:// dx.doi.org/10.1155/2014/139873.

Scandalios, J. G., Lingqiang, G., \& Polidoros, A. N. (1997). Catalases in plants: gene structure, properties, regulation, and expression. In J. G. Scandalios (Ed.), Oxidative stress and the molecular biology of antioxidant defenses. New York: Cold Spring Harbor Laboratory Press.

Schmittgen, T. D., \& Livak, K. J. (2008). Analyzing real-time PCR data by the comparative CT method. Nature Protocols, 3(6), 1101-1108. http://dx.doi.org/10.1038/nprot.2008.73.

Sen, S., \& Chakraborty, R. (2011). The role of antioxidants in human health (ACS Symposium Series, Vol. 1083). Washington: American Chemical Society. http://dx.doi.org/10.1021/bk-2011-1083.ch001.

Shi, H., Jiang, C., Ye, T., Tan, D. X., Reiter, R. J., Zhang, H., Liu, R., \& Chan, Z. (2015). Comparative physiological, metabolomic, and transcriptomic analyses reveal mechanisms of improved abiotic stress resistance in bermudagrass [Cynodon dactylon (L). Pers.] by exogenous melatonin. Journal of Experimental Botany, 66(3), 681-694. http://dx.doi.org/10.1093/jxb/eru373. PMid:25225478.

SourceForge (2020). JcolorGrid. Retrieved from http://sourceforge.net/ projects/jcolorgrid/

Stadtman, E. R., \& Berlett, B. S. (1998). Reactive oxygen-mediated protein oxidation in aging and disease. Drug Metabolism Reviews, 30(2), 225-243. http://dx.doi.org/10.3109/03602539808996310.

Sugimoto, M., \& Sakamoto, W. (1997). Putative phospholipid hydroperoxide glutathione peroxidase gene from Arabidopsis thaliana induced by oxidative stress. Genes \& Genetic Systems, 72(5), 311-316. http:// dx.doi.org/10.1266/ggs.72.311.
Swatek, K. N., \& Komander, D. (2016). Ubiquitin modifications. Cell Research, 26(4), 399-422. http://dx.doi.org/10.1038/cr.2016.39.

Ünyayar, S., \& Çekiç, F. (2005). Changes in antioxidative enzymes of young and mature leaves of tomato seedlings under drought stress. Turkish Journal of Biology, 29(4), 211-216. Retrieved from https:// dergipark.org.tr/tr/pub/tbtkbiology/issue/11727/140014

Ünyayar, S., Keleş, Y., \& Çekiç, F. Ö. (2005). The antioxidative response of two tomato species with different drought tolerances as a result of drought and cadmium stress combinations. Plant, Soil and Environment, 51(2), 57-64. http://dx.doi.org/10.17221/3556-PSE.

Van Camp, W., Capiau, K., Van Montagu, M., Inzé, D., \& Slooten, L. (1996). Enhancement of oxidative stress tolerance in transgenic tobacco plants overproducing Fe-superoxide dismutase in chloroplasts. Plant Physiology, 112(4), 1703-1714. http://dx.doi.org/10.1104/ pp.112.4.1703. PMid:8972606.

Van Camp, W., Willekens, H., Bowler, C., Van Montagu, M., Inzé, D., Reupold-Popp, P., Sandermann, H. Jr., \& Langebartels, C. (1994). Elevated levels of superoxide dismutase protect transgenic plants against ozone damage. Bio/Technology, 12, 165-168.

Wang, J., Zhang, H., \& Allen, R. D. (1999). Overexpression of an Arabidopsis peroxisomal ascorbate peroxidase gene in tobacco increases protection against oxidative stress. Plant \& Cell Physiology, 40(7), 725-732. http://dx.doi.org/10.1093/oxfordjournals.pcp.a029599.

Wang, Y., Wisniewski, M., Meilan, R., Cui, M., Webb, R., \& Fuchigami, L. (2005). Overexpression of cytosolic ascorbate peroxidase in tomato confers tolerance to chilling and salt stress. Journal of the American Society for Horticultural Science, 130(2), 167-173. http:// dx.doi.org/10.21273/JASHS.130.2.167.

Wu, H. M., Chi, K. H., \& Lin, W. W. (2002). Proteasome inhibitors stimulate activator protein-1 pathway via reactive oxygen species production. FEBS Letters, 526(1-3), 101-105. http://dx.doi.org/10.1016/ S0014-5793(02)03151-4.

Wu, J., Zhang, J., Li, X., Xu, J., \& Wang, L. (2016). Identification and characterization of a PutCu/Zn-SOD gene from Puccinellia tenuiflora (Turcz.) Scribn. et Merr. Plant Growth Regulation, 79(1), 55-64. http://dx.doi.org/10.1007/s10725-015-0110-6.

Yabuta, Y., Motoki, T., Yoshimura, K., Takeda, T., Ishikawa, T., \& Shigeoka, S. (2002). Thylakoid membrane-bound ascorbate peroxidase is a limiting factor of antioxidative systems under photo-oxidative stress. The Plant Journal, 32(6), 915-925. http://dx.doi.org/10.1046/j.1365-313X.2002.01476.x.

Yu, X., Robinson, J. F., Sidhu, J. S., Hong, S., \& Faustman, E. M. (2010). A system-based comparison of gene expression reveals alterations in oxidative stress, disruption of ubiquitin-proteasome system and altered cell cycle regulation after exposure to cadmium and methylmercury in mouse embryonic fibroblast. Toxicological Sciences, 114(2), 356-377. http://dx.doi.org/10.1093/toxsci/kfq003.

Zámocký, M., Gasselhuber, B., Furtmüller, P. G., \& Obinger, C. (2012). Molecular evolution of hydrogen peroxide degrading enzymes. Archives of Biochemistry and Biophysics, 525(2), 131-144. http:// dx.doi.org/10.1016/j.abb.2012.01.017.

Zhang, L., Sun, L., Zhang, L., Qiu, H., Liu, C., Wang, A., Deng, F., \& Zhu, J. (2017). A Cu/Zn superoxide dismutase gene from Saussurea involucrata Kar. \& Kir., SiCSD, enhances drought, cold, and oxidative stress in transgenic tobacco. Canadian Journal of Plant Science, 97(5), CJPS-2016-0180. http://dx.doi.org/10.1139/CJPS-2016-0180.

Zhou, Y., Liu, S., Yang, Z., Yang, Y., Jiang, L., \& Hu, L. (2017). CsCAT3, a catalase gene from Cucumis sativus, confers resistance to a variety of stresses to Escherichia coli. Biotechnology, Biotechnological Equipment, 31(5), 886-896. http://dx.doi.org/10.1080/13102818.2017.1360797. 